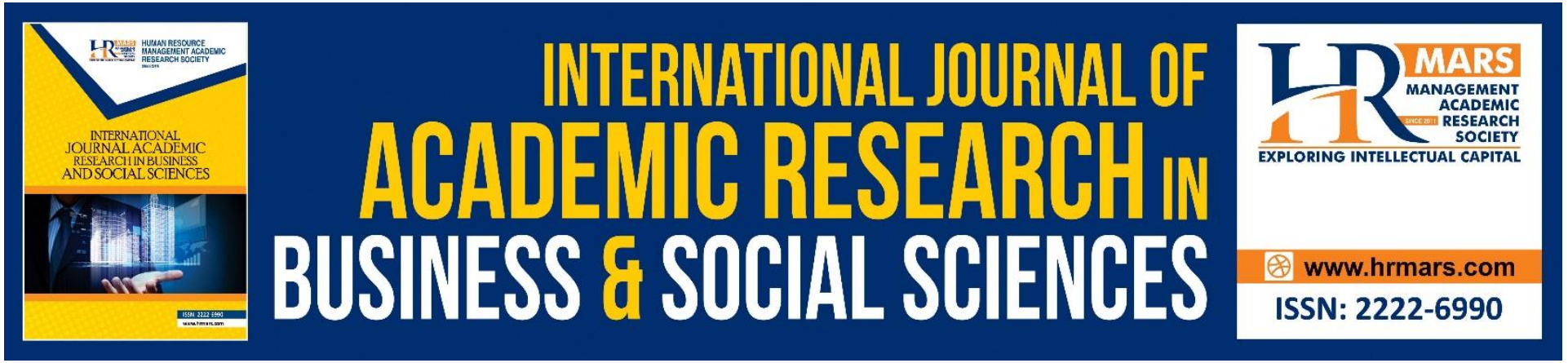

\title{
The Malaysian Armed Forces Religious Corps (MAFRC): Role and Perspectives on Middle East Issues
}

Burhanuddin Jalal, Badlihisham Mohd Nasir, Sayuti Ab Ghani, Amnah Saayah Ismail

To Link this Article: http://dx.doi.org/10.6007/IJARBSS/v11-i6/10374 DOI:10.6007/IJARBSS/v11-i6/10374

Received: 23 April 2021, Revised: 25 May 2021, Accepted: 11 June 2021

Published Online: 29 June 2021

In-Text Citation: (Jalal et al., 2021)

To Cite this Article: Jalal, B., Nasir, B. M., Ghani, S. A., \& Ismail, A. S. (2021). The Malaysian Armed Forces Religious Corps (MAFRC): Role and Perspectives on Middle East Issues. International Journal of Academic Research in Business and Social Sciences, 11(6), 1502-1513.

Copyright: (c) 2021 The Author(s)

Published by Human Resource Management Academic Research Society (www.hrmars.com)

This article is published under the Creative Commons Attribution (CC BY 4.0) license. Anyone may reproduce, distribute, translate and create derivative works of this article (for both commercial and non-commercial purposes), subject to full attribution to the original publication and authors. The full terms of this license may be seen

at: http://creativecommons.org/licences/by/4.0/legalcode

Vol. 11, No. 6, 2021, Pg. 1502 - 1513

http://hrmars.com/index.php/pages/detail/IJARBSS

JOURNAL HOMEPAGE

Full Terms \& Conditions of access and use can be found at http://hrmars.com/index.php/pages/detail/publication-ethics 


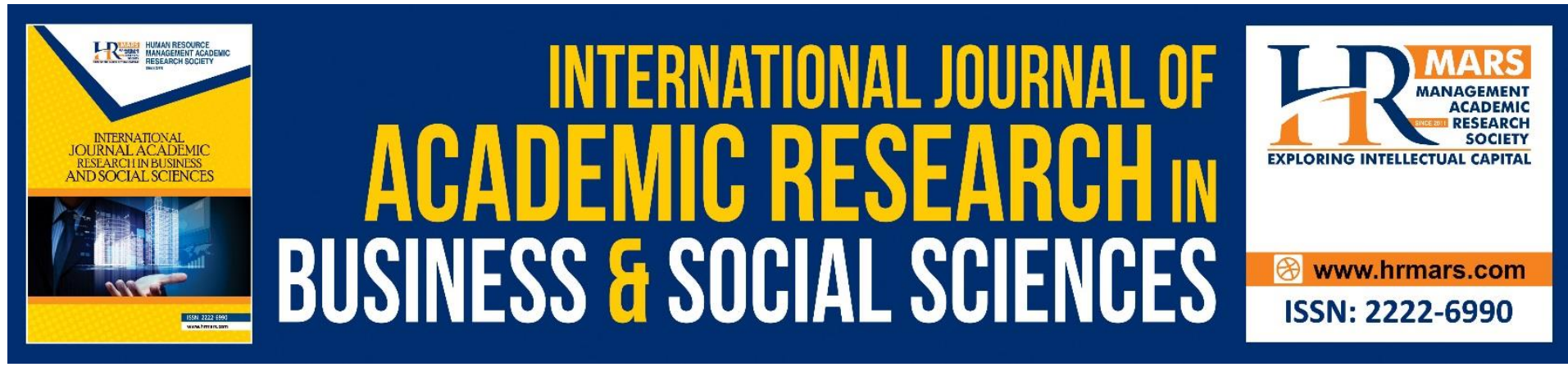

\title{
The Malaysian Armed Forces Religious Corps (MAFRC): Role and Perspectives on Middle East Issues
}

\author{
Burhanuddin Jalal ${ }^{1}$, Badlihisham Mohd Nasir², Sayuti Ab \\ Ghani $^{1}$, Amnah Saayah Ismail ${ }^{1}$ \\ ${ }^{1}$ National Defence University of Malaysia (NDUM), ${ }^{2}$ University Technology of Malaysia \\ (UTM) \\ Email: burhanuddin@upnm.edu.my
}

\begin{abstract}
The Malaysian Armed Forces Religious Corps (MAFRC) (Malay: Kor Agama Angkatan Tentera, KAGAT) was established in 1985. The Islamic da'wah efforts of the AFRC in military institutions have built an appreciation of Islam among its members to form the spiritual and mental strength in order to have a strong fighting force to defend the religion, nation and country. This article will discuss the role of the MAFRC in assisting the Malaysian Armed Forces in mitigating the negative effects of Middle Eastern conflicts such as terrorism, radicalism, Shiite ideology and members of the Armed Forces misunderstanding the concept of jihad. Library research, interviews and observations have been used for the success of this writing. In general, MAFRC has played a role in helping to solve the problems that occur among the members of the Malaysian Armed Forces (MAF) as a consequence of the unrest in the Middle East.
\end{abstract}

Keywords: Religion, Middle East, terrorism, Malaysian Armed Forces

\section{Introduction}

Islamic da'wah is an invitation or calls towards the acceptance and appreciation of Islamic teachings and values. This aspiration can be realized through the systematic management and planning of da'wah in accordance with the Qur'an recommendations so that the da'wah is conveyed and disseminated wisely and effectively. Regarding the awareness to deliver Islamic da'wah more effectively and build military personnel who are faithful and pious while also serving excellently and effectively, Islamic da'wah efforts have been implemented more widely and organized in the Malaysian Armed Forces organization. This paper will discuss the implementation of da'wah to convey the message and to provide understanding and appreciation of Islam to all MAFs members carried out by the Malaysian Armed Forces Religious Corps (MAFRC) in the Malaysian Armed Forces organization.

In addition, this paper will also discuss

- military-diplomatic relations with friendly countries and 
- the role of MAFRC to assist the Malaysian Armed Forces in mitigating the negative effects of Middle Eastern conflicts such as terrorism, radicalism, Shiite ideology and the misunderstanding of the concept of jihad among members of the MAF.

\section{Religious Services in the Malaysian Armed Forces}

The Malaysian Armed Forces Religious Corps (MAFRC) was officially established on 16 April 1985, following several efforts to create a special institution that handles religious and spiritual affairs in the Malaysian Armed Forces (KAGAT, 2005). The MAFRC's duties and responsibilities so broad that it encompasses all three branches of the Malaysian Armed Forces, namely the Malaysian Army (MA), the Royal Malaysian Navy (RMN) and the Royal Malaysian Air Force (RMAF). Since membership in the MAF mostly of Malay Muslims, it is appropriate for an organization under the MAF to be given the mandate to instil Islamic values among its members. At that time, the establishment of MAFRC was timely because, following history, the country had inherited the British military's pattern of leadership and administration since before independence (Awang, 1998).

The Constitution of Malaysia, in article 3 (1), states that "Islam is the religion of the federation, but other religions may be practised peacefully in any part of the Federation" (Federal Constitution, 2007). Because religion is one of the important features of Malaysia, it is appropriate to strive for and apply Islamic values to the country's Public Service procedures following the provisions of the Constitution as mentioned in Article 3 (1) of the Constitution. Federation of Malaysia (Abdul Hamid 1990). In general, Islamic activities in Malaysia after independence divided into two categories. First, official activities carried out by the government through the Department of Islamic Development Malaysia, as well as religious activities and programs organized by the Islamic Religious Council in the states. Second, religious activities carried out informally by the people and the public through nongovernmental organizations such as residents' associations, the Malaysian Islamic Welfare Association, the Malaysian Islamic Youth Force, and others (Azmi, 1980).

\section{Establishment of the Malaysian Armed Forces Religious Corps (MAFRC)}

The awareness of continuing to promote the eminence of Islam or syiar in the service of the Malaysian Armed Forces, particularly among the early generation of religious officials in the Ministry of Defence, certainly inherited the continuation of the struggle of Rasulullah swt, his companions and also the previous Islamic clergy and scholars. The challenge to continue this Islamic syiar has existed since the time of Rasulullah swt as mentioned by Majid Khadduri (1969) in his book War and Peace in the law of Islam:

"Allah gave Prophet Muhammad four swords (for fighting the unbelievers): the first against polytheist, which Muhammad himself fought; the second against apostates, which Caliph Abu Bakr fought; the third against the people of the book, which caliph 'Umar fought with; and the fourth against dissenters, which caliph Ali fought with".

The highlight of the da'wah process carried out by Rasulullah swt, in the early stages, Islam was circulated 'silently' among family and closest friends. A few years after receiving the first revelation, he began to preach openly until he was threatened by the enemy, and his safety was constantly threatened and insulted by his people. The same type of struggle to spread, to elevate the Islamic syiar as well as the efforts to appreciate the religion and da'wah, 
has also been experienced in the service of the Malaysian Armed Forces, the only difference being the challenges that must be overcome.

As a result of the sociological and political changes of the country and society, especially in the 1980s, there have been efforts to apply Islamic values in the government sector and military organizations. Following the developments, ideas and efforts to develop religious services as a corps under MAF services began to operate. In addition, other factors drive the establishment of MAFRC to bring religious members closer to militarization, namely:

(a) Planning, coordinating, and executing Islamic preaching and appreciation efforts for all MAF officers and members

(b) Provides and develops the teaching of Islamic knowledge with a focus on moral height, attitude, and nature (spirit de corps), as well as understanding in the true sense of military service according to Islamic views.

(c) Implement and enforce all Islamic rules, laws and orders decided by the Federal Islamic Religious Council and the states.

(d) Assists in efforts to enhance military morale in conjunction with the MAF war mission (Jalal, 2018).

The 238th Armed Forces Council Conference on November 29, 1984, approved a special Armed Forces Religious Corps service scheme covering technical aspects, nursing, emoluments, and the duration of service of officers and other members of the rank (Minutes of 238th Armed Forces Council Meeting). Following that, on March 29, 1986, the Armed Forces Council (AFC) approved the terms of service for Islamic Affairs Officers under the Department of Public Service to the Ministry of Defence under the military service scheme (249th Armed Forces Council Meeting Minutes, 1986). The establishment of the AFRC at that time intended to achieve the following goals:

(a) Meet the religious needs of MAF members and their families.

(b) Provide officers and Islamic education to the military community in times of peace, emergency or war.

(c) Develop a firm moral, tenacity and discipline among MAF members through the application of Islamic values appropriate to time and circumstances.

(d) Resolve issues of Islamic religious administration per legislation that has been enforced over time, particularly in sharia affairs and in relation to MAFs and the public.

(e) Strive to take care of whatever the authorities deem necessary for the good and development of Islam in MAFs (2005)

\section{Islamic Mental and Spiritual Construction Programme}

The AFRC has adopted The Islamic Mental and Spiritual Construction Policy to provide a solid education and appreciation of Islam to every Malaysian Muslim citizen who has served in the Malaysian Armed Forces. This policy requires every Muslim member of the Malaysian Army to receive 857 hours of Islamic education and programmes in a year for Islamic mental and spiritual construction, with specific guidance and guidelines issued from time to time (MAF Board Council, PMAT 9/91).

In addition to the existing physical training policy, two types of construction are presented in this published policy, to produce soldiers with physical, mental and spiritual endurance. The construction form is as follows:

(a) Mental resilience gained through the study of Islamic knowledge that includes Fardhu 'Ain and Fardhu Kifayah. 
(b) Spiritual endurance, as well as an authentic and accurate understanding of Islamic practice.

Through the mental endurance programme, every Muslim member serving in the Malaysian Armed Forces can and will be able to properly execute the demands of Fardhu 'Ain and Fardhu Kifayah. In the Malaysian Armed Forces, any actions or practices that contradict religious instruction are prohibited. As a result, while a member is serving the military, they must:

i. Maintain a mature, steady, and clear mind free of any negative elements, preventing them from being influenced by the flow of false thoughts that obscure the true teachings of Islam.

ii. Receive basic education of Islam which includes the following:
a. Basic education Fardhu 'Ain.
b. Basic education Fardhu Kifayah
c. Jihad education
d. Family education
e. Moral education
f. Leadership education
g. Al-Qur'an and Sunnah education
h. Education of worship
i. Education of Islamic civilization
j. Tasawur Islam.

All training centres, formations, and teams must provide at least 857 hours a year to enable members under their governance to receive Islamic education as prescribed. In terms of spiritual resilience, all Malaysian Muslim military members will be trained and educated throughout their service to become soldiers with Muslim characteristics, mukmin and muhsin (MAF Board Council, PMAT 9/91).

\section{The Malaysian National Defence Policy (NDP)}

Since its independence in 1957, Malaysia has developed policies and the military in protecting its security and maintaining its sovereignty. The development of the defence system since 1957, and the modernization of the armed forces since 1990, has enabled Malaysia to maintain its sovereignty (Zainuddin, 2004; Aaron, 2005). In general, from 1957 to 2016, Malaysia's National Defence Policy went through a long period of time with various dimensions of threat (Nathan, 2008; Simpson, 2013). The growing development of security threats, that are not only subject to conflicts, crises, and war (use of force), but also include non-traditional threats such as terrorist, drugs, economy, disease, border dispute, and so on, capable of destroying a country after the year of 1991 and 2000. Security threats during the Cold War era (1950-1991) and after the Cold War (1991-present) influenced the formation of Malaysia's National Defence Policy (Rahman, 1997).

The military development also influenced Malaysia to produce official documents on defence policy from the 1960s to the 1980s. The government proposed the NDP document in 1981 and presented it for cabinet approval in 1986, but it failed (Jeshrun, 1980). However, the National Security Council approved the NDP proposal for DPN reference until 2010.

The Malaysian government has established three principles in the national defence policy of self-reliance defence, regional cooperation, and external assistance. The practice of selfreliance defence principles has been a priority of the NDP's development, with the military focusing on policies to protect the country's security and sovereignty by exercising its capabilities rather than relying on foreign countries. 
In this regard, Othman (2002) states, "Malaysia, as an independent country, has recognized that the preservation of national interests and the best security is accomplished through efforts towards self-reliance capabilities, which is the core of national defence policy." This principle emphasizes the Armed Forces as an important component of the country's selfreliance structure. It includes not only the combat forces but also the logistics support network, as well as military-industrial cooperation aligned with the priorities of the national development programme. In this case, self-reliance should not be limited to the efforts of the Armed Forces but should include all government and people-related agencies.

The principle of self-reliance defence is equivalent to the principles of regional cooperation and external assistance, whereas realism advocates for each country to be self-reliance in terms of defence. The term "self-reliance", or "self-help", refers to a concept practised by realism, in which each country must believe and rely on itself, rather than relying on 'nonstate actors'. In this context, Harun (1997) asserts that following the withdrawal of British troops from the region, and since the end of 1972, the approach has been self-reliance and the existence of regional cooperation in the face of external threats.

Self-reliance defence entails a country's reliance on its defence resources rather than on external powers, meaning a country's defence must prioritize self-reliance while also considering regional cooperation and external assistance. As a result, the principles of regional cooperation and external assistance are only options, while the country must implement the principle of self-reliance defence. This highlight the flaws in Malaysia's National Defence Policy (NDP), as it has established the principles of regional cooperation defence and external assistance in line with self-reliance defence principles, although each country should strive to be self-reliance. Kasim (2002) further states:

"This is Malaysian concept of self-reliance. No doubt, it is a good concept, but its implementation is only known to the armed forces, whereas the other agencies involved are not knowing it or ignorant of its existence. Self-reliance should be a national commitment, which weaves through various facets of political, social, and economic activities towards the principal objectives of preserving national security. Presently, most of the defence-related agency is going for the economic gains rather than developing the defence need of the nation". (Kasim, 2002).

When it comes to security, every country must rely on itself. In the context of Malaysia, the NDP itself is self-reliance. While regional cooperation and external assistance are optional principles. This is because the country must be self-reliance, whereas actions to cooperate and seek external assistance are optional to the country, for example, to increase or maintain power in ensuring a country's safety and survival in the international system. The following is the National Defence Policy Diagram of self-reliance: 


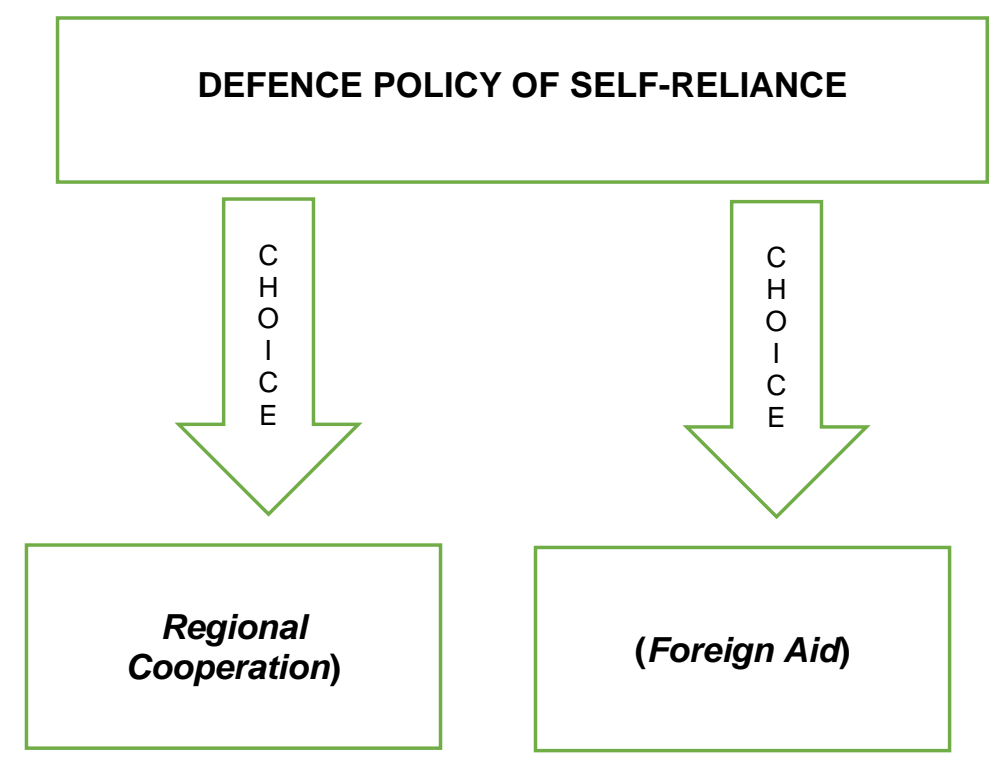

Figure 1: National Defence Policy from a Realism Perspective (Source: Ministry of Defence of Malaysia, 1995)

\section{National Defence Policy and Military Relations Diplomacy}

Recent developments in the region have highlighted several new challenges and uncertainties in terms of threats to national defence. As a preparation to face any possibility that will affect Malaysia's sovereignty, independence and integrity, the Malaysian government issued the National Defence Policy in 2010. The main objective of the National Defence Policy is to protect and defend the country's interests at the core of sovereignty, territorial integrity and economic well-being. Furthermore, Malaysia has rejected the use of threats or violence to resolve international disputes, preferring instead to settle peacefully. The country's Defence Policy also explains defensive practice, which is the practice of defence diplomacy through the implementation of bilateral and multilateral relations (National Defence Policy, 2010).

Malaysia recognizes defence diplomacy as an important effort of prevention or escalation of conflicts that threaten peace and stability. Among the actions towards this effort are steps to build confidence, transparency, the formation of positive norms and the establishment of communication channels. This is accomplished through joint training, information sharing, senior officer visits, officer exchanges, and the provision of military education and training (Abd Razak, 2009).

Among the bilateral cooperation are those between ASEAN countries, which are constantly enhancing their defence diplomacy efforts through training programs at the Malaysian Defence Cooperation Program (MDCP). In addition, Malaysia maintains close ties with other partner countries through the cooperation of the Five Nations Joint Defence Forces or the FPDA (Five Pact Defence Agreement). Furthermore, developments in the upper Asia Pacific region are still influenced by relations between the United States, China and Japan. Malaysia recognizes that the United States will remain superior power and will play a significant role in shaping the regional strategic environment. Thus, Malaysia's defence cooperation with the United States is in support of efforts to foster confidence, as well as ensuring that the country's interests are protected in terms of both security and economy. This is demonstrated by the implementation of the Treaty of Amity and Cooperation in Southeast Asia 1976 (TAC) in 2009. Malaysia welcomes the resolution of tensions between 
the two countries in the context of East Asia involving China-Taiwan relations. Similarly, in the South Asian situation involving India and Pakistan, which has always supported regional stability (National Defence Policy, 2010).

It should be emphasized that Malaysia has always supported the efforts of the United Nations (UN) and the international community to ensure universal peace and security. Malaysia has taken a proactive approach to address global issues under its Foreign Policy. Malaysia's participation under the UN flags began in Congo in 1960. Until now, Malaysia has participated actively in various UN peacekeeping operations including Military Observers, Battalion Group, UN Headquarters and Technical Staff Group. The Malaysian Armed Forces involvement in the UN mission is not limited to the execution of peacekeeping tasks, but also the enforcement of peace and other humanitarian work. Malaysia is also a signatory to the UN Standby Arrangements 1996, which states that an Infantry Battalion is ready to operate under UN auspices if necessary. To date, $25000 \mathrm{MAF}$ members have participated in various UN operations (Sire, 2009).

\section{Middle East Conflict}

The Middle East conflict is one of the most prolonged conflicts and has yet to be resolved. Many parties are involved in efforts to resolve the conflict, including the Organization of Islamic States (OICs), the United Nations (UN) and major powers such as the United States and Russia. In general, there are three major issues at stake in this conflict:

i. Economics. The conflict in West Asia has affected the world economically especially on global crude oil prices, as oil is a necessary component in today's industry.

ii. Socio-political. Generally, there are various Arab tribes in the Middle East including Arab, Persian, Jewish, Turkish and Kurdish. There are significant differences between these Arab tribes and resolving the conflict will be difficult.

iii. Ideology. The conflict in West Asia also created a schism between the Sunni and Shiite sects of Islam. Furthermore, the West Asian conflict has 'generated' takfiri ideology, terrorism and terrorist organization such as ISIS, DAESH and other fragmented terrorist organizations.

Malaysia has never been formally involved in the Middle East conflict in the terms of military relations in the past. However, under its previous leadership (Barisan Nasional), the Malaysian government sent several troops to Saudi Arabia to join a nine-state alliance led by Saudi Arabia to assist the Yamen government in fighting the Houthi rebels and loyalists of former President Ali Abdullah. However, the government today (Pakatan Harapan) withdrew this force because the alliance was not formally formed and did not fall under the jurisdiction of the UN (Berita Harian, 2018).

Although Malaysia currently has one Battalion of MAF members participating in the UN peacekeeping mission of the United Nations Interim Force in Lebanon (UNIFIL), which is a peacekeeping mission under UN Resolutions 425 and 426 to restore international security and peace to ensure Israel's withdrawal from Lebanon.

\section{The Role of MAFRC in Addressing the Effects of Middle Eastern Conflict Issues}

In general, the military plays an important role in determining a state's safety, stability, security and sovereignty (Ali, 2004). The requirements for a country's military forces are closely related to two factors: (1) security threats and (2) assisting a country's foreign policy. 
The MAFRC has implemented several measures to prevent the development and inclusion of violence or terrorist doctrine from infiltrating into MAF organizations. These measures include:

(c) Implementation of the Faith Shield Operation to suppress the concept and influence of DAESH, ISIS, terrorism, radicalism, Shiites and Wahabis.

(d) Strengthening the practice of fardhu 'ain

(e) Explain the meaning of jihad, Sunnah and Bidaah.

(f) Explain the issues of takfiri.

The Malaysian Armed Forces Religious Corps (MAFRC) role in assisting the Malaysian Armed Forces (MAF) in mitigating the direct effects of the Middle East conflict is as follows:

\section{Implementation of Hero Shield Operations and Faith Shield Operations to suppress terrorism, radicalism, Shiites and Wahabis.}

MAFs take every terrorist threat seriously, especially the latest threats from the DAESH or ISIS militant group. Various efforts and actions have been made by many involved preventing extremism and radicalism from spreading within the organization, as well as to combat the narrative and propaganda of the Islamic State in Iraq and Al-Sham (ISIS) also known as alDawla al-Islamiyyah fi Iraq wa ssh-Sham (DAESH). However, the fight against ISIS narratives remains less effective because there are still a few Muslims in general, as well as a few MAF members, who are drawn to the ISIS phenomenon. According to the survey and feedback from awareness programs implemented by the Perisai Wira Task Force, there are still a few MAF members who do not understand the history of the establishment, the characteristics and ideologies of this Daesh/ ISIS militant group, as well as the narratives that are spread through their propaganda channels, primarily through social media platforms (MAF Headquarters BSPP, 2018).

According to MAFRC Director, Major General Dato' Kamaruddin Mamat explained, "Hero Shield Ops are aimed at curbing the spread of doctrine by international terrorist groups and DAESH while Faith Shield Ops are aimed at informing officers and members of the military about the perversion of faith as well as the heresy that exists in our country." (Interview with Mej Jen Dato' Kamaruddin Mamat on October 16, 2019).

MAFRC always assist MAFs in addressing this issue, as DAESH or ISIS recruit MAF members based on the following factors:

a. Trained and experienced military personnel, such as special forces members, technical, armament and explosives specialists.

b. Military members who have disciplinary issues, domestic strife and a negative attitude toward the organization and service.

c. Members who have superficial religious knowledge and a tendency to practice their ideology.

d. Members who are tempted to join an independent organization or group of preachers until they are fully committed to the group's leaders.

e. Members who are confused or misled by sentiments, information or news from reading material that is easily accessible through social media / open reading material without guidance.

f. Members who are delusional to identify themselves, have social problems and are negative minded such as self-deprecating and neglected, leading to an 'anti-establishment attitude. 
g. Members who have a desire to approach and deepen Islam to atone for the sins they have committed through shortcuts without regard to the law in Islamic teaching.

h. Members who are concerned about what is happening in conflict zones such as Afghanistan, Syria, Iraq and South Mindanao.

i. Members who have a proclivity for Islamic revolutionary movements and frequently visit Islamic movement website where they discuss jihad and martyrdom.

\section{i. Explanation of the jihad and war issue.}

Jihad means "enlighten all efforts and abilities, both in the form of words or desire". The most comprehensive definition of a jihadist is, "Jihad is to make every effort to achieve the truth that one desires. The reality of jihad is an earnest effort to achieve things that Allah loves such as faith and righteous charity while rejecting things that He despises, such as liberation, fervour and evil". The definition encompasses all types of jihad that a Muslim can engage in, including his hard work of obeying Allah by obeying His commandments and avoiding His prohibitions. This includes his efforts to persuade others (Islam or infidelity) to obey Allah S.W.T and his efforts in combating unbelievers to raise the words of Allah and so on. An attempt is said to be a jihad if it qualifies, which is done 'in the way of God'. Therefore, all efforts that are not in the way of Allah S.W.T cannot be categorized as jihad.

ii. All fighters in the DAESH Islamic Caliphate or ISIS are paid salaries (wages) and are rewarded with various rewards such as marriage allowances and the ability to sell/buy prisoners of war. Thus, fighting in the Islamic Caliphate of DAESH or ISIS is no longer considered jihad, but rather a field of work. Therefore, is such a struggle referred to as jihad? Another thing Muslims around the world should be aware of is that what is happening in Iraq and Syria is now a "political war" to determines who has power (politics) and who controls the natural resources (oil). Hence, political war is not a jihadist field.

iii. The word jihad with various meanings is mentioned 31 times in the Quran. While the word Qital (war), appears only four times. It should be noted that the definition of jihad in the Quran and Hadith is broader and more general than just war. If war means "against the armed forces", then jihad means "enlightening all efforts to face the enemy", whether the enemy is a vicious human being or a demon that every Muslim must confront, or even himself. Because of the various definitions of jihad, there are numerous ways to implement it. There is jihad done with soul, wealth or speech (arguments or with the Quran). All in the name of explaining and spreading Islam to the general public. All of the above types and meanings of jihad are mentioned in the Quran and Sunnah. Muslims should be aware and informed that jihad with soul or wealth (such as war or joining the military as an example) as dictated in the Quran should be carried out in the way of Allah S.W.T and to raise the word of Allah. Among the things to follow for us to remain in Islamic rule, is to always associate jihad with high humanitarian ideals. One thing to keep in mind is that jihad in Islamic philosophy is not for conquest, occupation, domination of other people's natural resources, oppression and degradation of other nations or other materialistic purposes that have triggered war in great civilization since ancient times (Zin, 2006). 


\section{Closing}

In conclusion, the role of the MAFRC in the Middle East conflict is to assist MAFs in providing knowledge, exposure and guidance to MAF members on the dangers of extremism, radicalism and terrorism, which could harm themselves, services and national security. The information was intended to assist the team to identify military personnel who were likely to support the DAESH or ISIS militant struggle as well as to prevent extremism and radicalism from spreading within MAF organizations. To summarize, Islamic da'wah in the Malaysian Armed Forces (MAF) must be strengthened, revitalized and reinforced. Aspects of prayer and worship practice must be strengthened following the sophistication of weapons, and soul and heart fortitude must be balanced with physical and mental strength. The Word of Allah (s.w.t) in Surah al-Anfal (8:45): "O believers! when you encounter a company (enemy) then you must stand firm and say and remember Allah (with prayer) much, that you may succeed (achieve victory)".

\section{References}

Al-Basemeih, A. (1987). Tafsir pimpinan Al-Quran kepada pengertian Al-Quran Ar-Rahman Edisi ke lapan. 1987. Kuala Lumpur: Bahagian Hal Ehwal Islam, Jabatan Perdana Menteri Malaysia.

Awang, M. R. (1996). Pembinaan sahsiah tentera dalam Islam dan kaitannya dengan ketenteraan masa kini. Tesis Sarjana Pengajian Islam. Bahan Tidak diterbitkan. Bangi: Universiti Kebangsaan Malaysia.

Abd Rahman, A. (1997). Keselamatan dan Kepentingan Nasional. Bangi: Penerbit UKM Universiti Kebangsaan Malaysia.

Ali, S. A. (2004). Isu-isu keselamatan dan pertahanan dalam Jurnal Sorotan Darat, Bil 40. Kuala Lumpur: Markas Pemerintahan Latihan Tentera Darat.

Baginda, A. R. (2009). Malaysia's Defence \& Security Since 1957. Kuala Lumpur: Malaysian Strategic Research Centre.

Bahagian Staf Perisikan Pertahanan. (2018). Garis Panduan Pencegahan Fahaman Ekstremisme Dan Radikalisme Dalam Angkatan Tentera Malaysia. Kuala Lumpur: Markas Angkatan Tentera Malaysia

Berita Harian. (2018). Isu Keselamatan negara, 5 Disember 2020.

Bradley, S. R. (2013). "Southeast Asia in the Cold War" dalam Robert J. McMahon [ed]. The Cold War in the Third World. Oxford: Oxford University Press, ms.52-58.

Chandran, J. (1980). Malaysia Defence Policy: A Study in Parliament Attitudes 1963-1974. Kuala Lumpur: Penerbit Universiti Malaya.

Dasar Pertahanan Negara. (2004). Perajurit. Kuala Lumpur. July. 55-58.

Harun, N. (1997). "Palapes" . Perajurit. Kuala Lumpur: Julai, 8 -43.

Harun, N. (2002). Dasar Pertahanan Menyeluruh: Sempena Hari Angkatan Tentera Malaysia. Perajurit. Kuala Lumpur: (7)17.

Harun, N. (2005). Batalion Standard Infantry. Perajurit. Kuala Lumpur: November, 3-7 Idris, A. S. (1983). 50 Tahun askar Melayu. Kuala Lumpur: Utusan Melayu Publication. Interview Session. (2019). Mejar Jeneral Dato' Kamaruddin Mamat. Markas Angkatan

Tentera, Kementerian Pertahanan Malaysia, Kuala Lumpur.

Jalal, B. (2018). Dakwah Askari di Malaysia. Nilai. Universiti Sains Islam Malaysia.

Jabatan Arah KAGAT (1992). Prosedur pelaksanaan tugas KAGAT. Kuala Lumpur: Markas Angkatan Tentera Malaysia. 
Jabatan Arah KAGAT (1992). Profesion ketenteraan dan bimbingan rohani. Kuala Lumpur: Markas Angkatan Tentera Malaysia.

Jabatan Arah KAGAT. (1982). Panduan umum kor. Kuala Lumpur: Markas Angkatan Tentera Malaysia.

Jabatan Arah KAGAT. (1986). Risalah KAGAT: Kuala Lumpur: Markas Angkatan Tentera Malaysia.

Jabatan Arah KAGAT. (2005). Di Persada Kegemilangan. Kuala Lumpur: Markas Angkatan Tentera Malaysia.

Jaafar, K. (2002). Influence of Bureaucratic Politics on Ministry of Defence Decision Making Process in Policy Formulation. Master Degree. Thesis. Bangi. Faculty of Social Science and Humanities

Ministry of Defense Malaysia. (2010). Dasar Pertahanan Negara. Kuala Lumpur: Kementerian Pertahanan Malaysia.

Khadduri, M. (1969). War and peace in the law of Islam. London: The John Hopkins Press.

Markas Angkatan Tentera Malaysia. (1991). Perintah Majlis Angkatan Tentera Malaysia PMAT 9/91. Kuala Lumpur: Markas Angkatan Tentera Malaysia

Mohamad, A. H. (1990). Konflik dan Pengharmonian. Kuala Lumpur: Utusan Publication \& Distributors Sdn Bhd

Nathan, K. S. (2008). "Malaysia and International Security: Role, Commitments, Issues, and Challenges". Kertas Kerja dibentang dalam Engaging Malaysian Modernity 50 Years and Beyond in the 6th International Malaysian Studies Conference, di Crowne Plaza Riverside Hotel, Kuching, Sarawak, Malaysia, pada tarikh 5-7 Ogos.

Shaharuddin, O. (2002). "Malaysian Armed Forces Modernisation: Would it Enhance National Development?". Tesis Master Tidak Diterbitkan. Bangi: Faculty of Social Sciences and Humanities Perlembagaan Persekutuan. Kuala Lumpur: International Law Book Servis.

Wan Abd Kadir, W. H. A. (19800. Islam di Malaysia: kedatangan dan perkembangan (Abad 720M). DIm Tamadun Islam di Malaysia. Kuala Lumpur: Persatuan Sejarah Malaysia.

Zin, A. A. (2006). Islam dan dakwah. Kuala Lumpur: Institut Kefahaman Islam Malaysia.

Zulkhairil, Z. (2004). MAF: Pertahankan Kedaulatan Bumi Bertuah. Perajurit, December, 53. 